\title{
The Chiloé Mw 7.6 earthquake of 25 December 2016 in Southern Chile and its relation to the Mw 9.51960 Valdivia earthquake
}

\author{
Dietrich Lange ${ }^{1}$, Javier Ruiz ${ }^{2}$, Sebastián Carrasco ${ }^{3}$, Paula Manríquez ${ }^{3}$ \\ (1) GEOMAR Helmholtz Centre for Ocean Research Kiel, Kiel, Germany \\ (2) Departamento de Geofísica, Facultad de Ciencias Físicas y Matemáticas, \\ Universidad de Chile, Santiago, Chile \\ (3) National Seismological Centre, University of Chile, Santiago, Chile
}

Keywords:

2016 Chiloé earthquake, Subduction Zone, Southern Chile, 1960 Valdivia Earthquake

Corresponding author: Dietrich Lange (email: dlange@geomar.de)

\begin{abstract}
On 25 December 2016, a Mw 7.6 earthquake broke a portion of the Southern Chilean subduction zone south of Chiloé Island, located in the central part of the Mw 9.5 1960 Valdivia earthquake. This region is characterized by repeated earthquakes in 1960 and historical times with very sparse interseismic activity due to the subduction of a young ( $\sim 15 \mathrm{Ma})$, and therefore hot, oceanic plate. We estimate the co-seismic slip distribution based on a kinematic finite fault source model, and through joint inversion of teleseismic body waves and strong motion data. The coseismic slip model yields a total seismic moment of $3.94 \times 10^{20} \mathrm{Nm}$ that occurred over $\sim 30 \mathrm{~s}$, with the rupture propagating mainly downdip, reaching a peak-slip of $\sim 4.2 \mathrm{~m}$. Regional moment tensor inversion of stronger aftershocks reveals thrust type faulting at depths of the plate interface. The fore- and aftershock seismicity is mostly related to the subduction interface with sparse seismicity in the overriding crust. The
\end{abstract}


2016 Chiloé event broke a region with increased locking and most likely broke an asperity of the 1960 earthquake. The updip limit of the main event, aftershocks, foreshocks and interseismic activity are spatially similar, located $\sim 15 \mathrm{~km}$ offshore and parallel to Chiloé Islands west coast. The coseismic slip model of the 2016 Chiloé earthquake suggests a peak slip of $4.2 \mathrm{~m}$ that locally exceeds the $3.38 \mathrm{~m}$ slip deficit that has accumulated since 1960 . Therefore, the 2016 Chiloé earthquake possibly released strain that has built up prior to the 1960 Valdivia earthquake.

\section{Introduction}

Subduction of the Nazca plate below the South American plate has resulted in various large earthquakes along the Chilean margin (e.g. Lomnitz, 2004). The earthquake activity along the Chilean margin is due to the convergence of the Nazca and South American plates, which are colliding at a rate of $6.6 \mathrm{~cm} / \mathrm{yr}$ and an obliquity of $18^{\circ}$ in southern Chile (Angermann et al., 1999). On December 25, 2016 at 14:22 UTC a magnitude 7.6 subduction earthquake occurred adjacent to the south of Chiloé Island (Figure 1). In spite of its magnitude and proximity to the city of Quellón, little damage was reported and no tsunami occurred.

On the mainland the $1000 \mathrm{~km}$ long Liquiñe-Ofqui fault zone (LOFZ, Figure 1) (Cembrano et al., 1996) is related to the oblique subduction, and resulting partitioning of deformation along the southern Chilean margin. This partitioning is reflected by the northward movement of a forearc sliver, with sparse current strike-slip faulting along the magmatic arc (Wang et al., 2007, Lange et al., 2008). The seismicity rate during the last decades (Figure 2) in Southern Chile is low and seismicity was mostly related to crustal faulting along the LOFZ. There were 
two phases of seismicity and deformation observed on the LOFZ, which is collocated with the magmatic arc running along the southern Chilean mainland (e.g. Lavenu and Cembrano, 1999). The first seismic sequence was related to a $M_{w} 6.2$ crustal earthquake in the Aysen region $2007\left(45.4^{\circ} \mathrm{S}\right)$ (e.g. Agurto et al., 2012), and was followed by a second sequence related to the eruption of Chaitén volcano in 2008 at $42.5^{\circ} \mathrm{S}$ (e.g. Watt et al., 2009).

The low level of interseismic activity is in contrast with the occurrence of large and great earthquakes related to the plate interface, with a suggested recurrence period of $\sim 285$ years deduced from the last two millennia (Cisternas et al., 2005, 2017). In particular, previous large ruptures occurred in 1575, 1737, 1837 and 1960. The southern Chilean (Valdivia) earthquake of May 22, 1960 is the largest instrumentally recorded earthquake, with a mainshock moment magnitude of Mw 9.5 (Cifuentes \& Silver, 1989). This earthquake initiated at the Arauco peninsula at $38.2^{\circ} \mathrm{S}$ and progressed $\sim 1000 \mathrm{~km}$ southwards until the rupture terminated near the edge of the subducting Nazca lithosphere, at the intersection of the Chile Rise with the Chilean trench (Figure 1). This north-south trending rupture produced remarkable changes in land levels (Plafker \& Savage, 1970). The 1960 mainshock was preceded by a series of foreshocks aligned in a NW-SE direction, which started on May 21, 1960 with a $\mathrm{M}_{\mathrm{w}} 8.1$ event (Cifuentes, 1989).

The age (and therefore temperature and density) of the subducting Nazca plate decreases drastically from $20 \mathrm{Ma}$ at latitudes of Chiloé Island, to virtually $0 \mathrm{Ma}$ at $46^{\circ} \mathrm{S}$ where the Chile Rise is currently subducting. The frequency of interseismic activity also decreases substantially toward the Chile Triple Junction (CTJ) (Figure 2). Estimates for the width of the rupture plane of the 1960 earthquake, which is inclined at an angle of $\sim 30^{\circ}$ below the Chilean mainland (Haberland et al., 2009; Lange et al., 2007), range between 125 and $150 \mathrm{~km}$ (Barrientos \& Ward, 1990). Thermal models from Völker et al. (2011) show a decreasing width $\left(180 \mathrm{~km}\right.$ at $38^{\circ} \mathrm{S}$ and $80 \mathrm{~km}$ at $\left.42^{\circ} \mathrm{S}\right)$ of the seismogenic zone (defined here by the 
$150^{\circ} \mathrm{C}$ and $350^{\circ} \mathrm{C}$ isotherms) with increasing latitudes due to the young age (and high temperature) of the subducting oceanic plate.

Plafker \& Savage (1970) measured vertical land-level changes at 166 sites along the extent of the 1960 earthquake rupture zone in 1968. Because the vertical displacements were measured eight years after the 1960 earthquake, the dataset likely includes postseismic deformation. Slip models for the 1960 earthquake, inverted from the land-level changes, indicate rupture of the subduction interface along an $850 \mathrm{~km}$ long fault, with the majority of slip offshore (Barrientos \& Ward, 1990). Moreno et al. (2009) inverted the slip of the 1960 earthquake based on a finite element model using a curved slab geometry, resulting in a smaller amount of slip at larger depths $(>80 \mathrm{~km})$, which has previously been interpreted as aseismic slip. Their slip model is characterised by 4 slip patches with more than $20 \mathrm{~m}$ of slip (Figure 1). One of these slip maxima is located offshore and south of Chiloé Island in the region of the 2016 Chiloé earthquake, midway along the 1960 Valdivia earthquake rupture. In this study we process seismological data in order to investigate the setting of the 2016 Chiloé earthquake and its relation to the forearc structure, and the 1960 Valdivia earthquake. Based on data from local, regional and teleseismic distances, we locate and determine properties of the main event, fore- and aftershocks of the 2016 Chiloé earthquake.

\section{Methods and data}

\subsection{Coseismic rupture based on teleseismic observations and local strong motion} stations

We used records from 8 strong motion stations (three components) located at local and regional distances that were downloaded from the database maintained by the Centro Sismológico Nacional (CSN, www.sismologia.cl) (Figure 3A). The ground-acceleration 
records were double integrated to obtain displacement, filtered between $0.015-0.035 \mathrm{~Hz}$, and resampled to $0.25 \mathrm{~s}$. Broadband teleseismic waveforms of the FDSN (Federation of Digital Seismograph Networks) (Figure 3B) were retrieved from the IRIS Data Management Centre (www.iris.edu). Teleseismic stations cover an epicentral distance from $30^{\circ}$ to $90^{\circ}$. In total 80 P-waves (vertical) and $40 \mathrm{SH}$-waves (horizontal transverse) were used. Processing of the teleseismic records included deconvolution of the instrument response, integration to obtain displacement, and windowing $80 \mathrm{~s}$ around the body wave arrivals, starting $10 \mathrm{~s}$ before the respective P- or SH-wave arrival time. The data were bandpass filtered between $1 \mathrm{~s}$ and $200 \mathrm{~s}$, and resampled to a $0.25 \mathrm{~s}$ sampling rate. The $1 \mathrm{D}$ regional velocity model used by the CSN for Central Chile (Massone, personal communication, 2016), was used to compute Green's Functions of near-field waveforms and teleseismic body waves. The kinematic finite-source inversion adopted in this study follows the method of Ide \& Takeo (1997). Ide \& Takeo (1997) expand the slip distribution using 2-D spatial and temporal basis functions, with the expansion coefficients being unknown parameters. Then, the spatiotemporal distribution of slip-rate is expanded as a linear combination of basis functions, each one defined by an isosceles triangle in strike, dip and time directions. To stabilize the inversion, temporal and spatial smoothing constraints were used as a priori information. The weighting parameters of smoothing constraints are determined by minimizing the Akaike's Bayesian Information Criterion (ABIC) (Akaike 1980). The non-negative least squares method of Lawson \& Hanson (1974) is used to solve the damped least square problem, which ensures positivity of the model parameters. The assumed fault plane strikes at $\mathrm{N} 2^{\circ} \mathrm{E}$ and follows the slab geometry along dip (Slab 1.0, Hayes et al. 2012). This was achieved by subdivision of the fault into four rectangular segments along dip, with widths of $25 \mathrm{~km}$ each, dipping with $13^{\circ}, 15^{\circ}, 17^{\circ}$, and $19^{\circ}$, from top to bottom, respectively. We set a total of 9,10 and 12 basis functions along 
strike, dip, and time directions, respectively, to represent the slip in one direction. The basis source-time function is an isosceles triangle with a duration of $3 \mathrm{~s}$.

We use 12 basis functions in the time domain, with each one having a duration of $3 \mathrm{~s}$ and $50 \%$ overlap, resulting in the total rise-time allowed being $19.5 \mathrm{~s}$. As the focal mechanism is mainly a reverse fault, the slip direction at each grid point is allowed to vary between $90^{\circ}+/-$ $45^{\circ}$. We set the maximum rupture velocity at $92 \%$ of the shear-wave velocity around the hypocentre depth. This value controls the propagation of a rupture front that expands radially from the hypocentre and defines the onset rupture time of the first knot of the slip-rate for each point on the fault when the rupture front reaches it. A slower rupture velocity than the maximum value is allowed using an appropriate choice for the expansion coefficients. In the joint inversion of strong motion and teleseismic data the relative weighting factors of 1 and 0.02 and were chosen in order to maintain a balance between the error fitting of the teleseismic data in comparison to the measured error of the strong motion data. Note, that this relative weighting factors between the datasets was chosen dependent on the number of available seismograms, effectively upweighting the strong motion stations which are located in the near-field (Figure 3, panel a and b). The measured error is defined as the L2 norm of the difference between data and synthetics, and normalized by the L2 norm of the data. The relative weighting of datasets is determined prior to including temporal and spatial smoothing constraints. The near-field Green's functions were computed using the numerical code AXITRA (Coutant, 1990), which is based on the discrete wavenumber method of Bouchon(1981). Teleseismic body wave Green's functions were computed using the approach of Kikuchi \& Kanamori (1991). Synthetic Green's functions were computed with a time-step of $0.25 \mathrm{~s}$, and filtered in the same frequency band as the respective observed datasets. 


\subsection{Fore- and aftershocks}

Foreshocks and aftershocks are based on data from networks $\mathrm{C}$ and $\mathrm{C} 1$ run by the CSN, and TC and VC networks from Sernageomin (Servicio Nacional de Geología y Minería, www.sernageomin.cl). Seismicity was located using NonLinLoc (Lomax, et al., 2000) and SeisComP3 (www.seiscomp3.org) using a local minimum 1D velocity model based on amphibious data and optimized for the region of Chiloé Island (Lange et al., 2007). Continuous data from up to 54 days prior to the 2016 Chiloé mainshock were manually reviewed, and 43 foreshocks based on 872 onset times were located. We reviewed 91 days after the mainshock until (26 March 2017) and found 222 locatable aftershocks with $3987 \mathrm{P}$ and S-arrival times (Figure 5). The mean hypocentral uncertainties are $4.1 \mathrm{~km}, 2.7 \mathrm{~km}$ and 5.6 $\mathrm{km}$ for the west-east, north-south directions and depths, respectively (Figure S1).

\subsection{Regional moment tensor inversion}

We inverted regional moment tensors of 17 stronger aftershocks from $\mathrm{P}$ and $\mathrm{S}$ body waves. For the inversion stations from networks $\mathrm{C}$ and $\mathrm{C} 1$ from the CSN, TC and VC (Sernageomin), events with epicentral distances of up to $4^{\mathrm{o}}$, good signal-to-noise ratio (SNR), and local magnitudes larger than Ml 3.8 were included. We used between 6 and 27 stations, and an average of 14 stations. Green's functions were computed using discrete frequencywavenumber integration (Bouchon, 1981), based on a local 1-D velocity (Lange et al., 2007), using double-couple point sources.

Before inversion, we deconvolved the instrument response, decimated, rotated, and then applied a bandpass Butterworth filter to the observed seismograms in a magnitude-dependent frequency range, predominantly $0.02-0.06 \mathrm{~Hz}$, slightly modified from ranges proposed by other authors (e.g. Kubo et al., 2002; Asano et al., 2011). Components with low SNR and 
poor fit were not used for the inversion. Based on the epicentre from the location routine using a local 1D velocity model (Lange et al., 2007) we searched for the centroid depth in depth intervals of $2 \mathrm{~km}$. The moment tensor was estimated through a grid search of the best double couple component in the time domain (Herrmann et al., 2011; Herrmann 2013). A grid search over all possible focal mechanisms was performed in increments of 5 degrees in strike, dip, and rake. Synthetic seismograms were filtered in the same frequency band as the observed seismograms. First, the waveform fits were evaluated with variance reduction (VR), and then the best solution was chosen based on the largest variance reduction. Figure S2 shows the moment tensor solution and fitting of synthetic and observed waveforms for the largest aftershock.

\section{Results}

\subsection{Coseismic rupture}

Figure 3 shows the final coseismic slip model obtained from joint inversion of teleseismic and strong motion data. The slip distribution is dominated by a large slip patch that covers a region of $\sim 40 \times 30 \mathrm{~km}^{2}$. The peak-slip reaches $\sim 4.2 \mathrm{~m}$, located to the north and downdip of the hypocentre, with some slip of about $2 \mathrm{~m}$ retrieved to the north and updip of the hypocentre. The total seismic moment computed is $3.94 \times 10^{20} \mathrm{Nm}$, and gives a moment magnitude of 7.67. The peak-moment-rate is $\sim 3 \times 10^{19} \mathrm{Nm} / \mathrm{s}$, and occurs $12 \mathrm{~s}$ after rupture nucleation, with most of the moment occurring over the first 30 s (Figure 3D). Figures S3 and S4 show the slip models and checkerboard tests when datasets are analysed separately and jointly, respectively. The final slip model obtained from joint inversion of strong motion and teleseismic data explains (1) the deeper slip patch seen when analyzing both datasets separately, and (2) the 
shallow slip (located to the north and updip of the hypocentre) retrieved when only using strong motion data.

The synthetic seismograms (Figure 3E) fit well with the observed near-field ground displacements, and the waveform misfit in terms of variance reduction (VR) is $89 \%$. We observe that the southernmost strong motion stations (stations A10Y and AY01, Figure 3A) show a poor fit in comparison to the nearest stations, which we relate to the locally heterogeneous velocity structure. The fit between observed and synthetic teleseismic waveforms is good for both P- and SH-waves (Figure 3F). Overall, amplitudes, polarities, and the main characteristics of the observed waveforms are well modelled by synthetics. The waveform misfit in terms of VR is $80 \%$. The total VR estimated from the joint inversion of datasets is $84 \%$. Figure S5 shows snapshots of the slip-rate taken every $1 \mathrm{~s}$ after the rupture nucleation. The rupture propagates rapidly during the first $10 \mathrm{~s}$ (reaching the maximum rupture speed), moving mainly to the north and downdip direction. We also observe rupture towards the updip and downdip directions during the first $10 \mathrm{~s}$, but at much less pronounced slip amplitudes. The rupture propagating to the north and in the updip direction slows down after $12 \mathrm{~s}$, and gradually stops. From $12 \mathrm{~s}$ onwards, the rupture continues breaking the north and downdip portion of the fault, suggesting a second re-rupturing episode. The overall peakslip rate retrieved is approximately $1.5 \mathrm{~m} / \mathrm{s}$.

\subsection{Hypocentral parameters of seismicity}

Interseismic microseismicity from the CSN catalogue $(2.1<\mathrm{Ml}<5.4,01 / 2008$ until $12 / 2016)$ and foreshocks $(1.3<\mathrm{Ml}<3.6)$ (Figure 6) occur predominantly in a cluster parallel to the coast of Chiloé Island, suggesting consistent spatial patterns of seismic moment release. Similarly, during the deployment of an amphibious seismic network in 2005 (Lange et al., 2007), seismicity along the plate interface was observed in predominantly thrust type events (Ml 4.0- 
4.4), with associated aftershock sequences at depths of 12 to $30 \mathrm{~km}$ (Figure 7). We observe an epicentral shift of $38 \mathrm{~km}$ between the NEIC catalogue $\left(73.951^{\circ} \mathrm{W}, 43.416^{\circ} \mathrm{S}\right.$ and $35.1 \mathrm{~km}$ depth) and our mainshock epicentre $\left(74.391^{\circ} \mathrm{W}, 43.517^{\circ} \mathrm{S}, 30 \mathrm{~km}\right.$ depth) (Figure 5, yellow symbols). S minus $\mathrm{P}$ arrival time difference of the closest station G007 (Figure 5) is $9.6 \mathrm{~s}$, which is in agreement with a $73 \mathrm{~km}$ distance to our hypocentre location. Because NEIC's hypocentre is located at only $40 \mathrm{~km}$ distance to the closest station, we think that it is mislocated, presumably due to stronger weighting of stations at regional distances, one-sided station geometry and the use of a global velocity model.

\subsection{Moment tensors}

Regional moment tensors for aftershocks reveal thrust type mechanisms and centroid depths inline with the geometry of the downgoing slab (Figure 5 and 6). The double couple mechanisms of the moment tensors indicate faulting at depths of the plate interface. The fault plane of the mainshock from the Global Centroid Moment Tensor Catalogue (gCMT) dips $21^{\circ}$ with a strike of $7^{\circ}$ inline with an easterly dipping plate interface.

\section{Discussion}

\subsection{Coseismic rupture}

The total accumulated slip deficit since 1960, based on a plate convergence rate of $66 \mathrm{~mm} /$ year (Angermann et al., 1999), is $3.66 \mathrm{~m}$ for full interplate locking. Taking into account a coupling estimate for the plate interface of $\sim 90 \%$ (Figure 5 and Moreno et al., 2011) the slip deficit is $\sim 3.3 \mathrm{~m}$. The coseismic peak-slip of the 2016 Chiloé event, with $4.2 \mathrm{~m}$, 
locally exceeds the $3.3 \mathrm{~m}$ slip deficit. Undoubtedly, the 2016 Chiloé event locally released slip that has accumulated since 1960. The region where the 2016 coseismic peak-slip exceeds the slip deficit is based on two grid points in the inversion, and the amplitude of peak slip contains some uncertainties, as indicated by the checkerboard tests (Figure S4). If the coseismic slip did indeed exceed the slip deficit that has accumulated since 1960, this implies that the 2016 Chiloé event released slip that accumulated prior to the 1960 Valdivia earthquake (i.e. the 1960 event did not fully release its strain to the same level as the 2016 event). The uncertainties of this slip consideration are inherited from the uncertainty of the 2016 Chiloé coseismic slip model and the coupling model. The effect of slip exceeding the slip deficit becomes even larger when assuming lower coupling values. A coupling of $75 \%$ results in a slip deficit of $2.75 \mathrm{~m}$ since 1960, of which $1.45 \mathrm{~m}$ would have to have accumulated prior to the 1960 Valdivia earthquake. Therefore, the main uncertainties are related to the coseismic slip model and the spatial resolution of the slip and coupling inversions. The peak-slip of $4.2 \mathrm{~m}$ from our seismological model agrees well with the peak slip inverted from static displacements using GPS receivers, of $\sim 4.5 \mathrm{~m}$ (Ruiz et al., 2017) and to the maximum slip of $4.7 \mathrm{~m}$ (coseismic and 14 days postseismic deformation) inverted from InSAR data (Xu, 2017). We therefore conclude that the coseismic slip in 2016 may have exceeded the deficit accumulated since the 1960 Valdivia earthquake and the strain release for a given region is larger than expected for slip predictable earthquake recurrence models (which state that the slip of an earthquake is proportional to the time since the prior event (Shimazaki and Nakata, 1980). Furthermore, the initial and final stresses of faulting would not be constant over a sequence of earthquakes cycles. In contrast, a peak slip on the order of slip deficit accumulated since 2016 earthquake would be in line with the slip predictable earthquake recurrence models. 
The 1960 Valdivia earthquake released an average slip of $17 \mathrm{~m}$ along an $850 \mathrm{~km}$ long and 130 $\mathrm{km}$ wide rupture (Barrientos \& Ward, 1990), accounting for 250-350 years of plate convergence (assuming a constant convergence rate) (e.g., Plafker \& Savage 1970). Cisternas et al. (2005) suggest that the 1960 event released the slip that has accumulated since the 1575 event, while two later earthquakes, in 1737 and 1837, left the fault partly loaded with slip deficit that the 1960 earthquake then expended. A similar exceedance of slip compared to the slip deficit since the last large event was described by Nocquet et al. (2017) for the Ecuadorian subduction zone.

The region of the Chiloé 2016 event is characterized by a patch of increased locking (Figure 1). The almost fully locked zone ( $>90 \%)$ is located slightly updip and south of the coseismic rupture patch (Figure 5), although the precise location of locking and the shift between peak slip and the locking patch is presumably not well resolved (Moreno et al., 2010, supplementary material). Moreno et al. (2010) suggest a spatial correlation of interseismic locking with coseismic slip for the Mw 8.8 Maule earthquake in Central Chile. Similar to the Chiloé earthquake, the Mw 8.2 Illapel 2015 earthquake ruptured a region of high locking (Tilmann et al., 2016). Our observations from the Chiloé event support the suggestion from Moreno et al. (2010) that interseismic locking might possibly be used to anticipate future ruptures in seismic gaps, given the fundamental assumption that locking and slip are similar. Although the Chiloé 2016 event is spatially located in the rupture zone of the 1960 earthquake we do not regard this event as an aftershock, due to the 56 years time difference between these events. The sparse background seismicity (between $41^{\circ}$ and $45^{\circ} \mathrm{S}$, Figure 2), and the coupling model (Figure 1), indicate new strain and stress accumulation during the last decades which were locally released during the 2016 Chiloé event. We cannot completely rule out that the Chiloé 2016 event may have been triggered by relaxation processes within the lower crust 
and the upper mantle as observed in the 1960 Chile earthquake region south of $38^{\circ} \mathrm{S}$ (Klotz et al., 2001, Moreno et al., 2011). For example, using offshore geodetic observations Sun et al. (2014) observe significant viscoelastic relaxation effects in the aftermath of the 2011 Tohoku earthquake. For the 1960 Valdivia rupture zone westward moving GPS sites south of $38^{\circ} \mathrm{S}$, located 300-400 km landward of the 1960 rupture region, suggest a post-seismic mantle stress relaxation or silent slip events on the plate interface at large depths (Khazaradze et al., 2002).

\subsection{Interseismic Activity}

Although the background seismicity is very sparse there are two sequences of historical seismic activity listed in the ISC-GEM catalogue since 1900 (Figure 2). On 2nd March 1919 a Mw 7.2 event occurred at $43^{\circ} \mathrm{S}$ beneath the South American mainland (Figure 1, yellow star). This event is listed in the ISC-GEM (Storchak et al., 2013) catalogue with a depth of $15 \mathrm{~km}+/-25 \mathrm{~km}$ and may therefore be related to the LOFZ. This sequence ended one week later with a Mw 6.8 earthquake further north (Figure 1). The second phase of pronounced activity is related to outer rise aftershocks (between $43^{\circ} \mathrm{S}-44.24^{\circ} \mathrm{S}$ ) starting with the $\mathrm{Mw} 9.5$ 1960 Valdivia earthquake, and ending in 1965 (Figure 2 and events indicated by stars, Figure 1). Later, the background seismicity subsequently returned to a very low rate until the 2016 Chiloé event. Seismicity in the decade before the Chiloé earthquake occurred mostly in a coastal parallel band of events offshore Chiloé Island and parallel to the coastline, likely related to the plate interface (Figure 8A) (Lange et al., 2007).

\subsection{Aftershocks}

Coseismic slip and aftershocks of the 2016 Chiloé event occurred in the same depth range

(Figure 7), but the 2016 mainshock occurred adjacent to, and south of Chiloé Island in a 
region with very sparse interseismic seismicity. Aftershock magnitudes and locations are not evenly distributed. While larger aftershocks are located in the south-western aftershock region (Figure 5), smaller magnitude events are located parallel to the northwest-southeast trending coastline of Chiloé's south coast (Figure 5). This uneven distribution of aftershock seismicity might be related to the heterogeneous stress distribution along the plate interface. Alternatively, the aftershock distribution may be controlled by deep-reaching NW-SE trending faults which are known elsewhere along the whole South Chilean forearc (e.g. Glodny et al., 2008, Sernageomin, 2003). However, faults related to the Miocene marine transgressive sediments of Chiloé's south coast are unknown so far (Sernageomin, 2003). Furthermore, most of the aftershocks activity is located at depths of the plate interface with sparse seismicity in the overriding crust (Figure 4).

\subsection{Structural setting of the 2016 Chiloé earthquake}

The overall crustal structure at latitudes of Chiloé Island (Figure 7) appears to be very similar to the structure further north at around $38^{\circ} \mathrm{S}$ (Haberland et al., 2009), suggesting limited lateral change along the South Chilean subduction zone. The vp model of the local earthquake tomography study from Lange (2008) reveals features such as the subducting plate (labelled Y. Figure 7), a wedge shaped crustal forearc (labelled W, Figure 7), sedimentary basins in the marine forearc and beneath the longitudinal valley (W and X, Figure 7). In the western part of the model the $7.8 \mathrm{~km} / \mathrm{s}$ contour line is inclined following the downgoing slab, whereas in the eastern part of the model the $7.8 \mathrm{~km} / \mathrm{s}$ contour shows a bulge ( $\mathrm{Z}$ in Figure 7 ). A similar, arched $7.8 \mathrm{~km} / \mathrm{s}$ vp contour line from local earthquake tomography, was found $500 \mathrm{~km}$ further north and interpreted as continental mantle (Haberland et al., 2009). 
Most of the marine forearc is characterised by very sparse interseismic activity with a sharp onset of events $\sim 15 \mathrm{~km}$ west of Chiloé Island (Figure 6 ), at a similar depth to that of the updip limit of the aftershock series of the 2016 event (Figure 5). This implies that the 2016 earthquake ruptured only the deeper part of the 1960 earthquake rupture zone (Figure 1). The shallow forearc between the trench and the seismicity band parallel to the coast of Chiloé Island is characterized by an almost complete absence of interseismic seismicity (Figure 6), but is thought to have ruptured during the $1960 \mathrm{Mw} 9.5$ Valdivia earthquake (Figure 1). Here, the plate interface is located beneath the Chiloé basin (Figure 7B, label W), and the aseismic behaviour of the shallowest few kilometres of the plate interface is inline with global observations of a shallow aseismic zone attributed to underplating of semi-consolidated and unconsolidated sediments (Byrne et al., 1988), or to a conditionally stable regime (Bilek et al., 2004).

The seismic behaviour in the downdip direction beneath Chiloé Island and the surrounding subduction zone can be classified in the domains suggested by Lay et al. (2012). The Chiloé event ruptured the seismogenic zone (domain B), and left the shallow domain A unruptured (Figure 8B). Domain A is the region of tsunami earthquakes (Kanamori, 1972), that produce large tsunamis relative to their seismic moment (M0), and are usually associated with long rupture duration, for both large and small earthquakes (Bilek et al., 2004; Şen et al., 2015). The continental crust above the plate interface in the shallow domain A is characterised by a sedimentary basin (Figure 7 and Scherwath et al., 2009), and extends from the trench close to the transition from aseismic to seismic behaviour $\sim 20 \mathrm{~km}$ west of Chiloé Island. A similar seismic band parallel to the coastline, updip of the coseismic rupture and separating the rupture domains in the downdip direction, is observed for some subduction zones such as for the region of the Sumatra Mw 8.72005 earthquake (Tilmann et al., 2010). Beneath Chiloé Island, both domain A and B broke during the 1960 earthquake, while the 2016 earthquake 
ruptured only domain B (Figure 8B). Domain C, located deeper than $\sim 35 \mathrm{~km}$ depth (Figure 8) did not contain any recorded aftershocks, but is characterized by sparse seismicity during the interseismic period. The location of the $350^{\circ} \mathrm{C}$ isotherm (based on a shallow inclined slab) at the latitude of Chiloé Island (Oleskevich et al., 1999) is close (20 km east) to the intersection of the slab with the continental mantle inferred from the tomography. In general most of the aftershocks, foreshocks and interseismic activity correlate with temperatures between $150^{\circ} \mathrm{C}$ and $350^{\circ} \mathrm{C}$ (Figure 8A), as expected for the seismogenic zone (Oleskevich et al., 1999). For the updip end, Oleskevich et al. (1999) estimate that the plate interface exceeds $100^{\circ} \mathrm{C} 25 \mathrm{~km}$ east of the trench. The resulting width of the thermal seismogenic zone at a latitude of $42^{\circ} \mathrm{S}$ is $100 \mathrm{~km}$. This value is in agreement with the width of the seismogenic zone based on a recent thermal model by Völker et al. (2011), which shows a seismogenic zone based on the $100^{\circ} \mathrm{C}$ and $350^{\circ} \mathrm{C}$ isotherms that widens from south to north along the South Chilean margin (from $80 \mathrm{~km}$ at $42^{\circ} \mathrm{S}$ to $180 \mathrm{~km}$ at $38^{\circ} \mathrm{S}$ ), due to the older and therefore colder subducting oceanic plate in the north.

\section{Conclusions}

The 2016 Chiloé event is the first significant event within the central and southern segment of the great Mw 9.5 Valdivia earthquake. The 2016 Chiloé event broke a region with locally increased coupling and a large slip of $30 \mathrm{~m}$ from the 1960 Valdivia earthquake. The 2016 rupture occurred in a deeper part of the 1960 earthquake, at depths of $\sim 10-30 \mathrm{~km}$, and in temperature domains inline with the seismogenic zone $\left(150-350^{\circ} \mathrm{C}\right)$. The updip limit of coseismic slip and aftershocks of the 2016 Chiloé event is spatially related to interseismic and foreshock activity occurring in a band of seismicity parallel to the coast of Chiloé Island. The faulting style determined using moment tensor inversion of larger aftershocks indicates thrust 
faulting. Hypocentral depths of foreshock and aftershocks are mostly at depths of the plate interface and the overriding crust is characterized by sparse seismicity. Comparison of the locking model with the coseismic peak slip of the 2016 Chiloé earthquake indicates that strain released in 2016 has accumulated at least since the 1960 Valdivia earthquake. Taking into account the uncertainties of the slip and locking models, we cannot rule out the possibility that some strain released in 2016 might have accumulated prior to the 1960 earthquake. If true, this would imply that the final stress after earthquakes may include stress accumulated over more than one seismic cycle and stress levels reached after the coseismic phase would not be constant over many earthquakes cycles. For the Ecuadorian subduction zone, a similar exceedance of slip in comparison to the slip deficit since the previous earthquake was described by Nocquet et al. (2017). The release of strain that has accumulated at least since 1960 indicates that the 2016 Chiloé earthquake should not be regarded as aftershock of the 1960 event.

\section{Acknowledgments}

We thank the Chilean National Seismological Centre (CSN) and the Chilean National Geological y Mining Service (Sernageomin) for providing station data. Javier Ruiz gratefully acknowledges the support from the Chilean National Science Foundation, Project FONDECYT No. 1170804. We are grateful to the Masters and crew of R/V Sonne cruise SO181 and all scientists who were involved in the preparation of the multibeam bathymetry. We thank Jess Hillman who contributed to this manuscript by carefully spell-checking and correcting grammar. Our special thanks go to Gavin Hayes and an anonymous reviewer for their constructive comments and suggestions. 


\section{References}

Agurto, H., Rietbrock, A., Barrientos, S., Bataille, K., Legrand, D., 2012. Seismo-tectonic structure of the Aysén Region, Southern Chile, inferred from the $2007 \mathrm{Mw}=6.2$ Aysén earthquake sequence. Geophys J Int 190, 116-130. doi:10.1111/j.1365-246X.2012.05507.x.

Akaike, H., 1980. Likelihood and Bayes procedure, in Bayesian Statistics, edited by J. M. Bernardo et al., pp. 143-166, Univ. Press, Valencia, Spain.

Angermann, D., Klotz, J., Reigber, C., 1999. Space-geodetic estimation of the Nazca-South America Euler vector. Earth Planet. Sci. Lett. 171 (3), 329-334.

Asano, Y., Saito, T., Ito, Y., Shiomi, K., Hirose, H., Matsumoto, T., Aoi, S., Hori, S., Sekiguchi, S., 2011. Spatial distribution and focal mechanisms of aftershocks of the 2011 off the Pacific coast of Tohoku Earthquake. Earth, planets and space, 63(7), 29.

Barrientos, S. \& Ward, S., 1990. The 1960 Chile earthquake: inversion for slip distribution from surface deformation. Geophysical Journal International, Volume 103, Issue 3, 589-598.

Bilek, S. L., T. Lay, and L. J. Ruff, 2004, Radiated seismic energy and earthquake source duration variations from teleseismic source time functions for shallow subduction zone thrust earthquakes, J. Geophys. Res., 109, B09308, doi:10.1029/2004JB003039.

Bouchon, M., 1981. A simple method to calculate Green's functions for elastic layered media, Bull. Seism. Soc. Am., Vol. 71, No. 4, pp. 959-971.

Byrne, D., D. Davis, and L. Sykes, 1988. Loci and maximum size of thrust earthquakes and the mechanics of the shallow region of subduction zone, Tectonics, 7(4), 833-857.

Cembrano, J., Hervé, F., Lavenu, A., 1996. The Liquiñe Ofqui fault zone: A long-lived intraarc fault system in southern Chile. Tectonophysics 259, 55-66.

Cembrano, J., Schermer, E., Lavenu, A., Sanhueza, A., 2000. Contrasting nature of deformation along an intra-arc shear zone, the Liquiñe-Ofqui fault zone, southern Chilean Andes. Tectonophysics 319, 129-149.

Cifuentes, I. L., 1989. The 1960 Chilean Earthquakes. J. Geophys. Res., 94(B1), 665-680.

Cifuentes, I. L. \& Silver, P. G., 1989. Low-frequency source characteristics of the great 1960 Chilean earthquake. J. Geophys. Res., 94(B1), 643-663.

Cisternas, M., Atwater, B.F., Torrejón, F., Sawai,Y., Machuca, G., Lagos, M., Eipert,A., Youlton,C., Salgado,I., Kamataki, T., Shishikura,M., Rajendran, C.P., Malik, J.K, Rizal, Y. \& Husni, M, 2005. Predecessors of the giant 1960 Chile earthquake. Nature 437, 404-407.

Cisternas, M., Garrett, E., Wesson, R., Dura, T., Ely, L.L., 2017. Unusual geologic evidence of coeval seismic shaking and tsunamis shows variability in earthquake size and recurrence in the area of the giant 1960 Chile earthquake. Marine Geology 385, 101-113. doi:10.1016/j.margeo.2016.12.007.

Coutant, O., 1990. Programme de Simulation Numérique AXITRA, Rapport LGIT, Université Joseph Fourier, Grenoble, France. 
Glodny, J., Echtler, H., Collao, S., Ardiles, M., Burón, P., Figueroa, O., 2008. Differential Late Paleozoic active margin evolution in South-Central Chile $\left(37^{\circ} \mathrm{S}-40^{\circ} \mathrm{S}\right)$ - the Lanalhue Fault Zone. J. S. Am. Earth Sci. 26 (4), 397-411. doi:10.1016/j.jsames.2008.06.001.

Haberland, C., A. Rietbrock, D. Lange, K. Bataille, and T. Dahm, 2009. Structure of the seismogenic zone of the south central Chilean margin revealed by local earthquake traveltime tomography, J. Geophys. Res., 114, B01317, doi:10.1029/2008JB005802.

Hayes, G.P.,Wald, D.J. \& Johnson, R.L., 2012. Slab1.0: a three-dimensional model of global subduction zone geometries, J. geophys. Res., 117, B01302, doi:10.1029/2011JB008524.

Herrmann, R.B., Benz, H., Ammon, C.J., 2011. Monitoring the Earthquake Source Process in North America. Bulletin of the Seismological Society of America 101, 2609-2625, doi:10.1785/0120110095.

Herrmann, R. B., 2013. Computer programs in seismology: An evolving tool for instruction and research. Seismological Research Letters, 84(6), 1081-1088, doi:10.1785/0220110096.

Ide, S., and M. Takeo, 1997. Determination of constitutive relations of fault slip based on seismic wave analysis, J. Geophys. Res., 102(B12), 27379-27391. doi:10.1029/97JB02675.

Kanamori, H. 1972, Mechanism of tsunami earthquakes, Phys. Earth Planet. Inter., 6, 346-359, doi:10.1016/0031-9201(72)90058-1.

Khazaradze, G., Wang, K., Klotz, J., Hu, Y., He, J., 2002. Prolonged post-seismic deformation of the 1960 great Chile earthquake and implications for mantle rheology. Geophys. Res. Lett. 29, 2050. doi:10.1029/2002GL015986.

Kikuchi, K., and H. Kanamori, 1991. Inversion of complex body waves - III, Bull. Seism. Soc. Am., Vol. 81, No. 6, pp. 2335-2350.

Klotz, J., Khazaradze, G., Angermann, D., Reigber, C., Perdomo, R., Cifuentes, O., 2001. Earthquake cycle dominates contemporary crustal deformation in central and southern Andes. Earth Planet. Sci. Lett. 193, 437-446. doi:10.1016/S0012-821X(01)00532-5.

Kubo, A., Fukuyama, E., Kawai, H., \& Nonomura, K. I., 2002. NIED seismic moment tensor catalogue for regional earthquakes around Japan: quality test and application. Tectonophysics, $356(1), 23-48$.

Lavenu, A., Cembrano, J., 1999. Compressional- and transpressional-stress pattern for Pliocene and Quaternary brittle deformation in fore arc and intra-arc zones (Andes of Central and Southern Chile). J. Struct. Geol. 21 (12), 1.669-1.691.

Lawson, C. L., and R. J. Hanson, 1974. Solving Least Squares Problems, Englewood Cliffs: PrenticeHall, New Jersey.

Lay, T., H. Kanamori, C. Ammon, K. D. Koper, A. R. Hutko, Y. Lingling, H. Yue, and M. Rushing, 2012. Depth-varying properties of subduction zone megathrust faults, J. Geophys. Res., 117, B04311, doi:10.1029/2011JB009133.

Lange, D., Rietbrock, A., Haberland, C., Bataille, K., Dahm, T., Tilmann, F., Flüh, E., 2007. Seismicity and geometry of the south Chilean subduction zone $\left(41.5^{\circ} \mathrm{S}-43.5^{\circ} \mathrm{S}\right)$ : Implications for controlling parameters. Geophys. Res. Lett. 34, L06311. doi: 10.1029/2006GL029190. 
Lange, D., Cembrano, J., Rietbrock, A., Haberland, C., Dahm, T., Bataille, K., 2008. First seismic record for intra-arc strike-slip tectonics along the Liquiñe-Ofqui fault zone at the obliquely convergent plate margin of the southern Andes. Tectonophysics 455 (1-4), 14-24. doi: 10.1016/j.tecto.2008.04.014.

Lange, D., 2008. The South Chilean Subduction Zone between $41^{\circ} \mathrm{S}$ and $43.5^{\circ} \mathrm{S}$ : Seismicity, Structure and State of Stress. Ph.D. thesis, University of Potsdam, urn: nbn:de:kobv:517-opus-18948, https://publishup.uni-potsdam.de/opus4-ubp/frontdoor/index/index/docId/1738.

Lomax, A., Virieux, J., Volant, P., and Berge, C., 2000, Probabilistic earthquake location in 3D and layered models: Introduction of a Metropolis-Gibbs method and comparison with linear locations, in Advances in Seismic Event Location, Thurber, C.H., and N. Rabinowitz (eds.), Kluwer, Amsterdam, 101-134.

Lomnitz, C., 2004. Major Earthquakes of Chile: A Historical Survey, 1535-1960. Seismol. Res. Lett., 75(3), 368-378.

Moreno, M.S., Bolte, J., Klotz, J., Melnick, D., 2009. Impact of megathrust geometry on inversion of coseismic slip from geodetic data: application to the 1960 Chile earthquake. Geophys. Res. Lett. L16310 (36). doi:10.1029/2009GL039276.

Moreno, M., Rosenau, M., Oncken, O., 2010. 2010 Maule earthquake slip correlates with pre-seismic locking of Andean subduction zone. Nature 467, 198-202. doi:10.1038/nature09349.

Moreno, M., et al., 2011. Heterogeneous plate locking in the South-Central Chile subduction zone: Building up the next great earthquake. Earth and Planetary Science Letters 305, 413-424, doi:10.1016/j.eps1.2011.03.025.

Müller, R. D., M. Sdrolias, C. Gaina, andW. Roest (2008), Age, spreading rates, and spreading asymmetry of the world's ocean crust, Geochem. Geophys. Geosyst., 9, Q0406, doi:10.1029/2007GC001743.

Nocquet, J.-M., Jarrin, P., Vallée, M., Mothes, P.A., Grandin, R., Rolandone, F., Delouis, B., Yepes, H., Font, Y., Fuentes, D., Régnier, M., Laurendeau, A., Cisneros, D., Hernandez, S., Sladen, A., Singaucho, J.-C., Mora, H., Gomez, J., Montes, L., Charvis, P., 2017. Supercycle at the Ecuadorian subduction zone revealed after the 2016 Pedernales earthquake. Nature Geosci 10, 145-149. doi: 10.1038/ngeo2864.

Oleskevich, D., R. Hyndman, and K. Wang, 1999. The updip and downdip limits to great subduction earthquakes: Thermal and structural models of Cascadia, south Alaska, SW Japan, and Chile, J. Geophys. Res., 104(B7), 14,965-14,991.

Plafker, G. \& Savage, 1970. J. C. Mechanism of the Chilean earthquakes of May 21 and 22, 1960. Geol. Soc. Am. Bull. 81, 1001-1030.

Ruiz, S., M. Moreno, D. Melnick, F. delCampo, P. Poli, J. C. Baez, F. Leyton, and R. Madariaga, 2017. Reawakening of large earthquakes in south central Chile: The 2016 Mw 7.6 Chiloé event, Geophys. Res. Lett., 44, doi: 10.1002/2017GL074133.

Scherwath, M., Contreras-Reyes, E., Flueh, E.R., Grevemeyer, I., Krabbenhoeft, A., Papenberg, C., Petersen, C.J., Weinrebe, R.W., 2009. Deep lithospheric structures along the southern central Chile margin from wide-angle P-wave modelling. Geophysical Journal International 179, 579-600. doi:10.1111/j.1365-246X.2009.04298.x. 
Şen, A.T., Cesca, S., Lange, D., Dahm, T., Tilmann, F., Heimann, S., 2015. Systematic Changes of Earthquake Rupture with Depth: A Case Study from the $2010 \mathrm{Mw} 8.8$ Maule, Chile, Earthquake Aftershock Sequence. Bulletin of the Seismological Society of America. doi:10.1785/0120140123.

Sernageomin, 2003. Mapa Geológico de Chile: versión digital, N4, CD-ROM, versión 1.0. Servicio Nacional de Geología y Minería. Servicio Nacional de Geología y Minería, Publicación Geológica Digital, Santiago, Chile.

Shimazaki, K., Nakata, T., 1980. Time-predictable recurrence model for large earthquakes. Geophys. Res. Lett. 7, 279-282, doi:10.1029/GL007i004p00279.

Storchak, D.A., Giacomo, D.D., Bondár, I., Engdahl, E.R., Harris, J., Lee, W.H.K., Villaseñor, A., Bormann, P., 2013. Public Release of the ISC-GEM Global Instrumental Earthquake Catalogue (1900-2009). Seismological Research Letters 84, 810-815. doi:10.1785/0220130034.

Sun, T., Wang, K., Iinuma, T., Hino, R., He, J., Fujimoto, H., Kido, M., Osada, Y., Miura, S., Ohta, Y., Hu, Y., 2014. Prevalence of viscoelastic relaxation after the 2011 Tohoku-oki earthquake. Nature 514, 84-87. doi:10.1038/nature13778.

Tilmann, F.J., Craig, T.J., Grevemeyer, I., Suwargadi, B., Kopp, H., Flueh, E., 2010. The updip seismic/aseismic transition of the Sumatra megathrust illuminated by aftershocks of the 2004 Aceh-Andaman and 2005 Nias events. Geophys. J. Int. 181(3), 1261-1274. doi:10.1111/j.1365-246X.2010.04597.x.

Tilmann, F., et al. 2016. The 2015 Illapel earthquake, central Chile: A type case for a characteristic earthquake? Geophys. Res. Lett. 43, 2015GL066963. doi:10.1002/2015GL066963.

Wang, K., Hu, Y., Bevis, M., Kendrick, E., Smalley, R., Vargas, R.B., Lauría, E., 2007. Crustal motion in the zone of the 1960 Chile earthquake: Detangling earthquake-cycle deformation and forearc-sliver translation. Geochem. Geophys. Geosyst. 8, Q10010. doi:10.1029/2007GC001721.

Watt, S. F. L., D. M. Pyle, T. A. Mather, R. S. Martin, and N. E. Matthews, 2009. Fallout and distribution of volcanic ash over Argentina following the May 2008 explosive eruption of Chaitén, Chile, J. Geophys. Res., 114, B04207, doi:10.1029/2008JB006219.

Völker, D., Grevemeyer, I., Stipp, M., Wang, K., He, J., 2011. Thermal control of the seismogenic zone of southern central Chile. J. Geophys. Res. 116, B10305. doi:10.1029/2011JB008247.

Xu, W., 2017. Finite-fault slip model of the 2016 Mw 7.5 Chiloé earthquake, southern Chile, estimated from sentinel-1 data, Geophys. Res. Lett., 44, doi:10.1002/2017GL073560. 


\section{Figures}

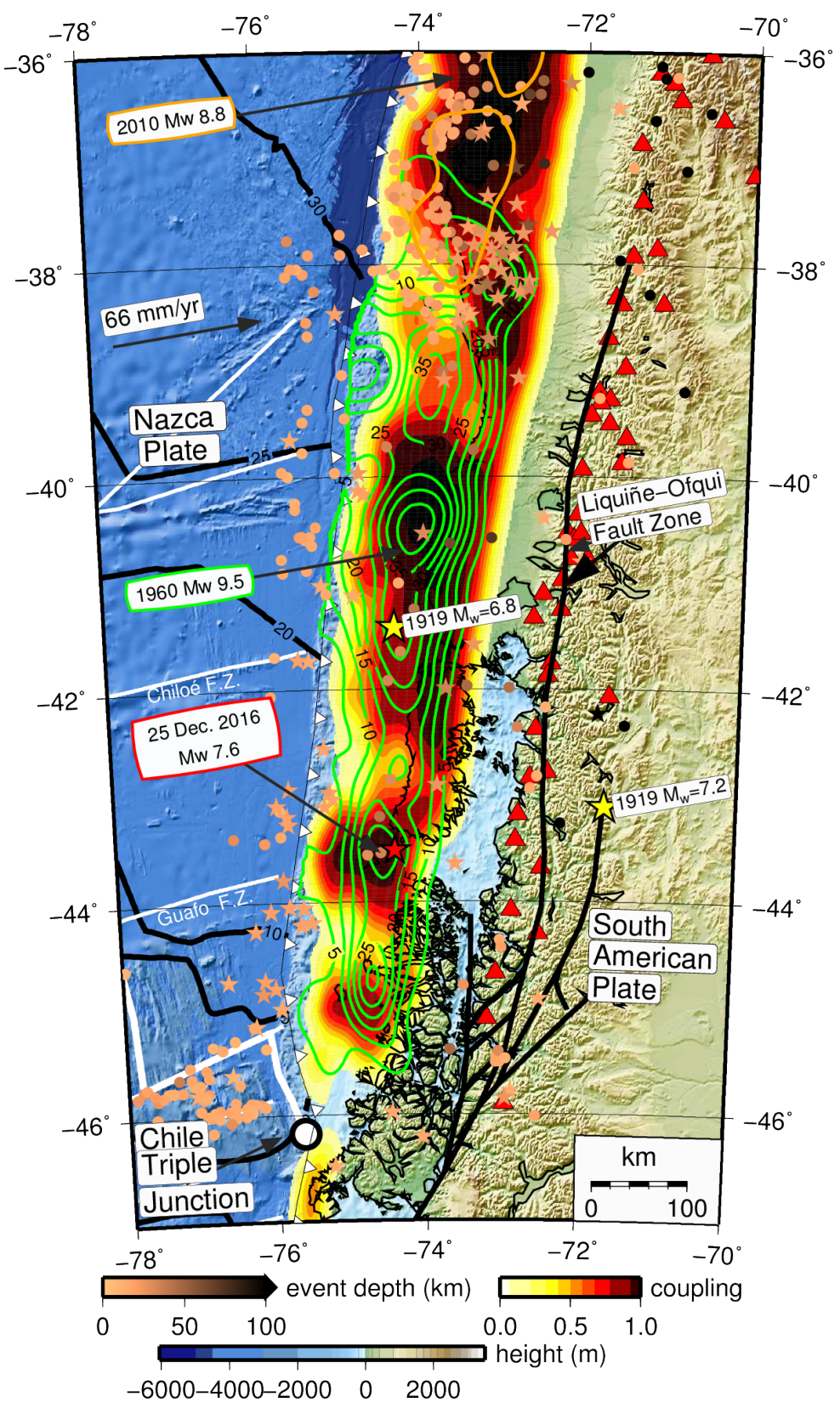

Figure 1: Tectonic setting of the 2016 Chiloé earthquake. The slip distribution of the 1960 earthquake (Moreno et al., 2009) is indicated with green lines (5 $\mathrm{m}$ slip contours) and plate coupling from Moreno et al. (2011) is shown colour coded. The hypocentre of the 2016 Chiloé earthquake is indicated by a red star. Seismicity is shown colour coded with depth (ISC-GEM catalogue, 01/01/1900-31/12/1975 with stars, gCMT (01/01/1976-01/02/2017 with circles). Two earthquakes from March 1919 are indicated with yellow stars. Oceanic plate ages from Müller et al. (2008). LOFZ after Cembrano et al. (2000), velocity of the Nazca plate relative to South America after Angermann et al. (1999), volcanoes are indicated by red triangles. 


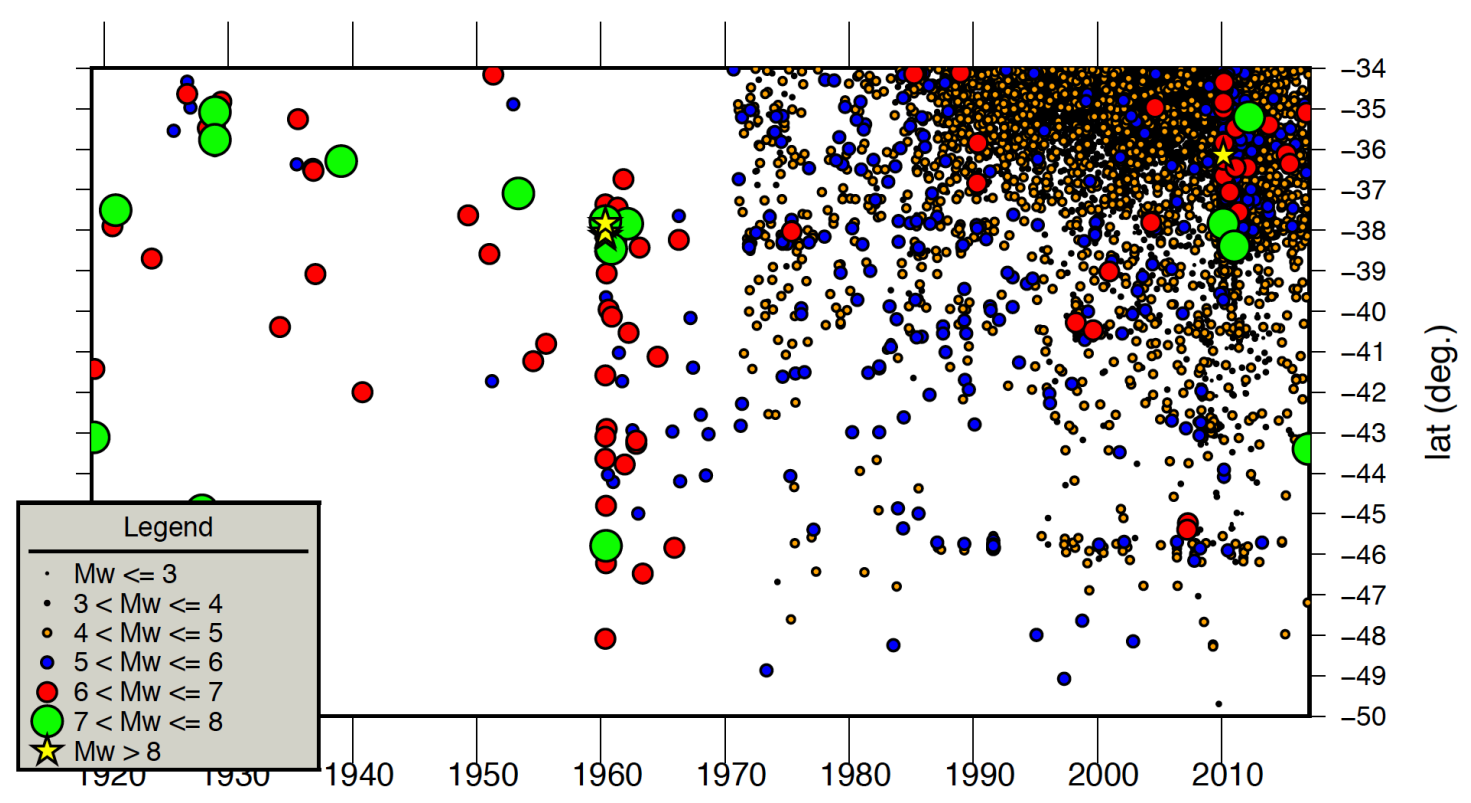

Figure 2: Temporal and trench lateral distribution of aftershocks. Top: Events from 1920 until 1961 from ISC-GEM Global Instrumental Earthquake Catalogue (Storchak et al., 2013) and events from January 1961 until 28 January 2017 from the NEIC catalogue. 
(c)

(a)

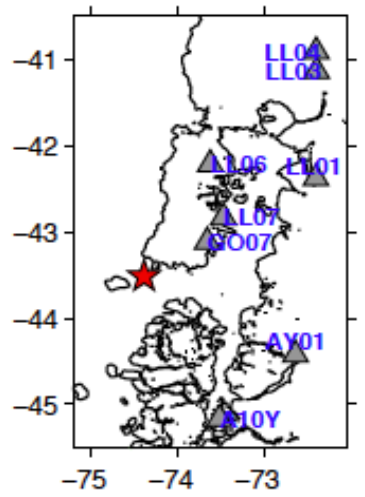

(b)

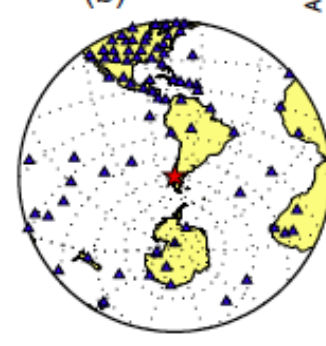

(e)
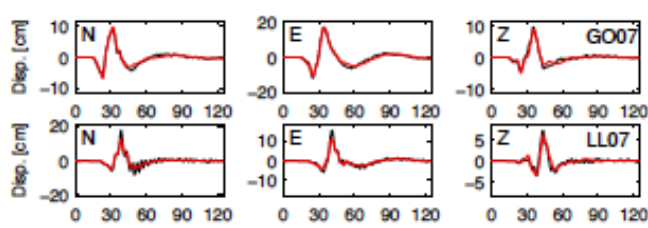

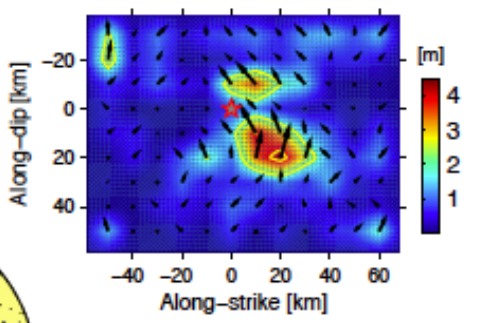

(f)

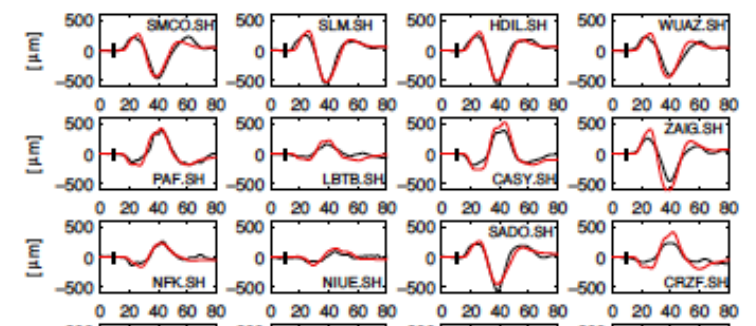

$\underline{\underline{\underline{E}}}$ (d)

$\times 10^{19}$

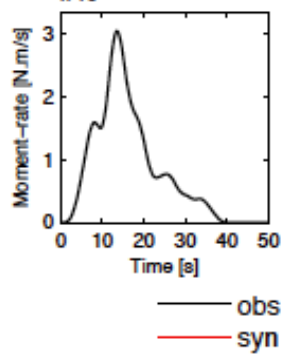

\section{syn}
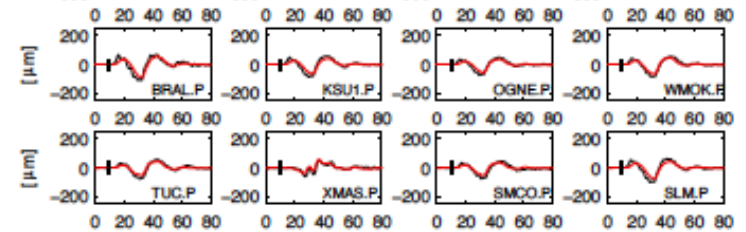

Figure 3: Coseismic slip model of the 2016 Mw 7.6 Chiloé earthquake from joint inversion of teleseismic body waves and strong motion data. (A) Map view showing the distribution of strong motion stations (grey triangles) and the hypocentre of the mainshock (red star) located by the CSN (B) Broadband stations (blue triangles) at teleseismic distance used in the inversion. Red star indicates the hypocentre of the 2016 Chiloe earthquake. (C) Map view of the final slip distribution. Black arrows correspond to the slip vector scaled to the slip amplitude. Red star indicates the location of the rupture nucleation. (D) Moment-rate function. (E) Fitting of observed (black line) and calculated (red line) ground displacements at the two closest strong motion stations. Station codes and components are indicated on the top of each set of traces. Start time of the records corresponds to the origin time. (F) Comparison of observed (black line) and synthetic (red line) teleseismic body waves at few representative stations. Station code name and the respective $\mathrm{P}$ - or $\mathrm{SH}$-wave record is shown inside each box. 


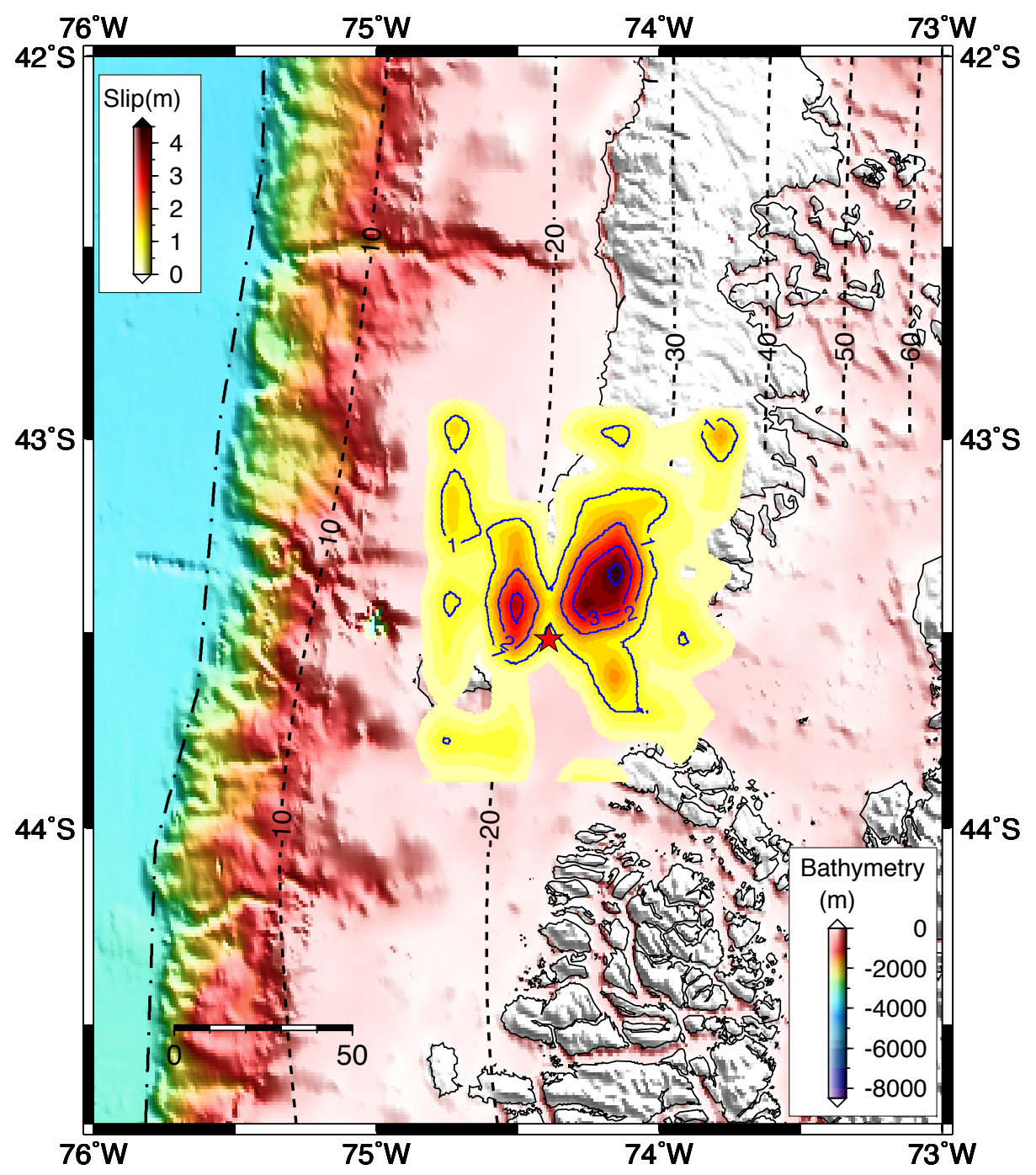

Figure 4: The coseismic slip distribution of the 2016 Chiloé earthquake is shown with a coloured grid and $1 \mathrm{~m}$ slip contours. Black dashed lines indicate the depth to the plate interface as defined by the global SLAB1.0 model (Hayes et al. 2012). The bathymetry was taken from the GEBCO (https://www.gebco.net). The red star indicates the hypocenter of the 2016 Chiloé earthquake. 


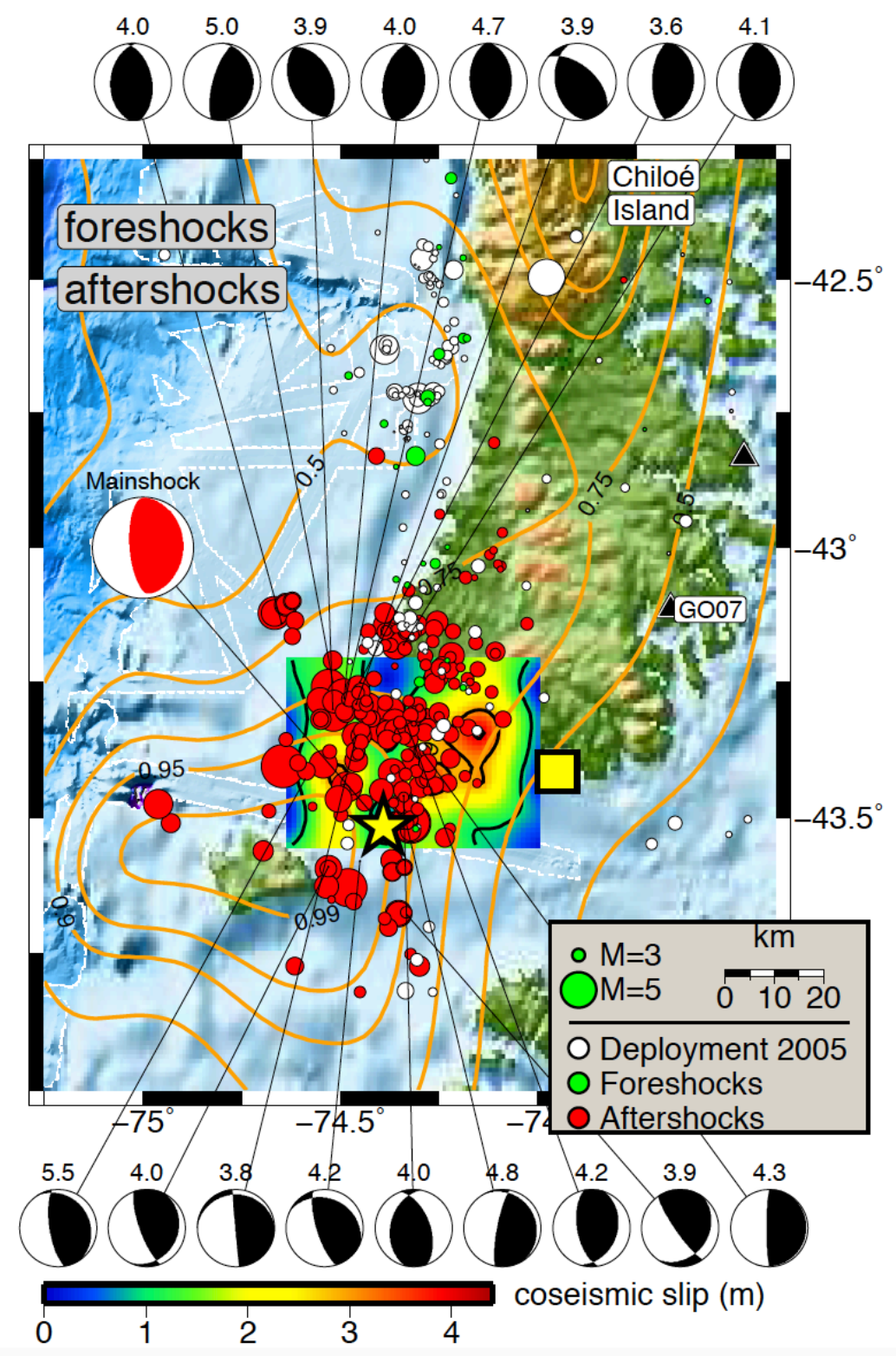

Figure 5: Fore- and aftershocks of the 2016 Chiloé event together with focal mechanisms from moment tensor inversion. Interseismic activity from 2005 based on an amphibious seismic network (white circles) (Lange et al., 2007). The coupling model of Moreno et al. (2011) is indicated with orange lines. The coseismic slip distribution of the 2016 Chiloé earthquake is shown with a coloured grid and $1 \mathrm{~m}$ slip contours. High-resolution multibeam bathymetry from RN Sonne cruise S0181 is encircled with a white line. Hypocentre from NEIC is indicated as a yellow square, hypocentre using the local stations is indicated with a yellow star. Moment tensor for the 2016 Chiloé mainshock from gCMT (www.globalcmt.org). 


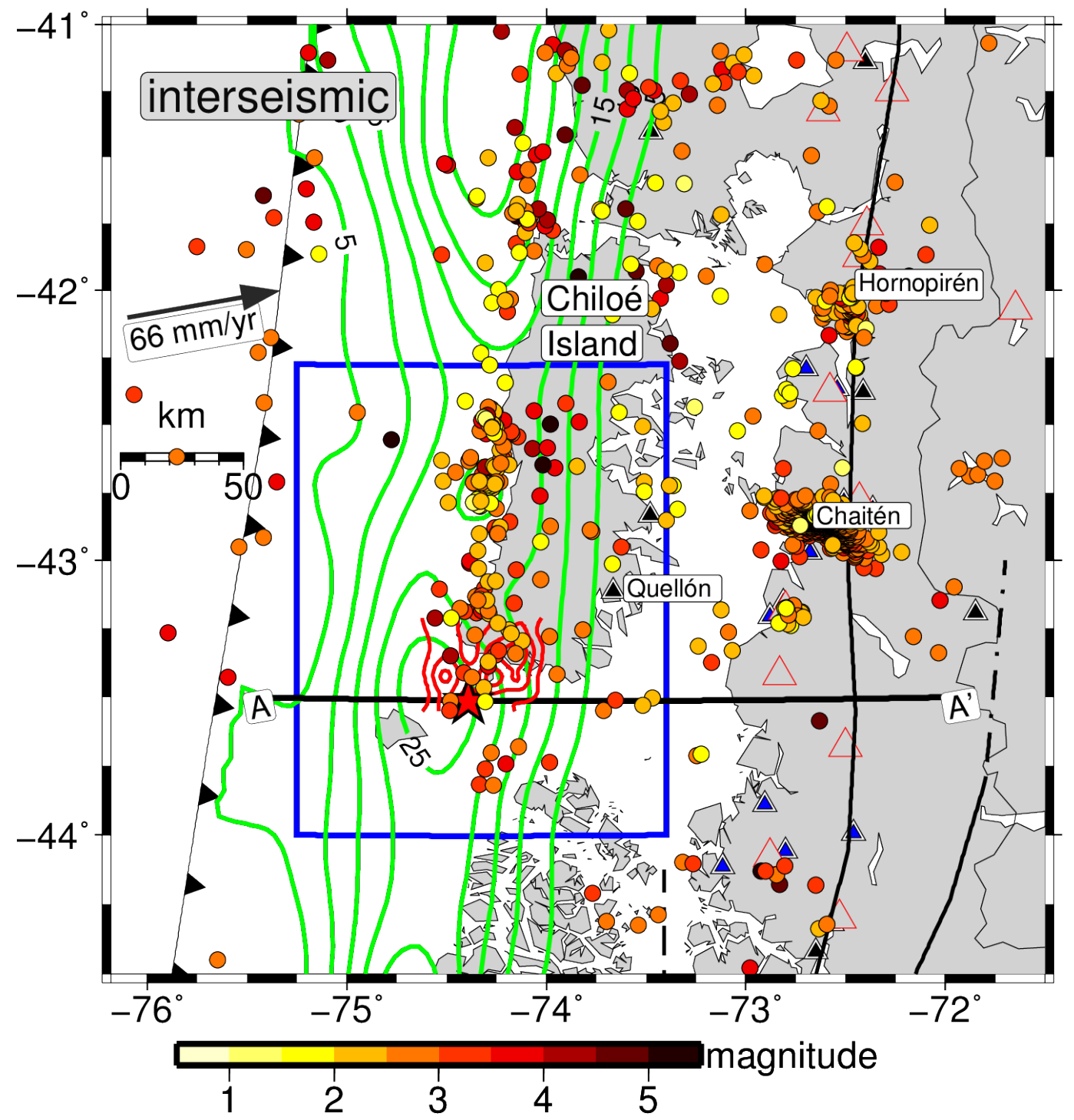

Figure 6: The 2016 Chiloé earthquake and interseismic activity in the region of Chiloé Island. Circles indicate interseismic activity (CSN catalogue, 01/01/2008 until 24/12/2016 and seismicity from Lange et al., 2007) together with the slip model of the 1960 Valdivia earthquake based on the inversion of land-level changes (Moreno et al., 2009) shown with green lines (5 $\mathrm{m}$ slip contours). Red lines indicate the $1 \mathrm{~m}$ slip contours of the 2016 Chiloé earthquake. Volcanoes are indicated with red triangles. Black (CSN) and blue (Sernageomin) triangles indicate local seismic stations used in this study. Blue box indicates location of figure 4. The location of the profiles shown in figures 6 and 7 are shown with a black line and labelled with $A-A$ '. 


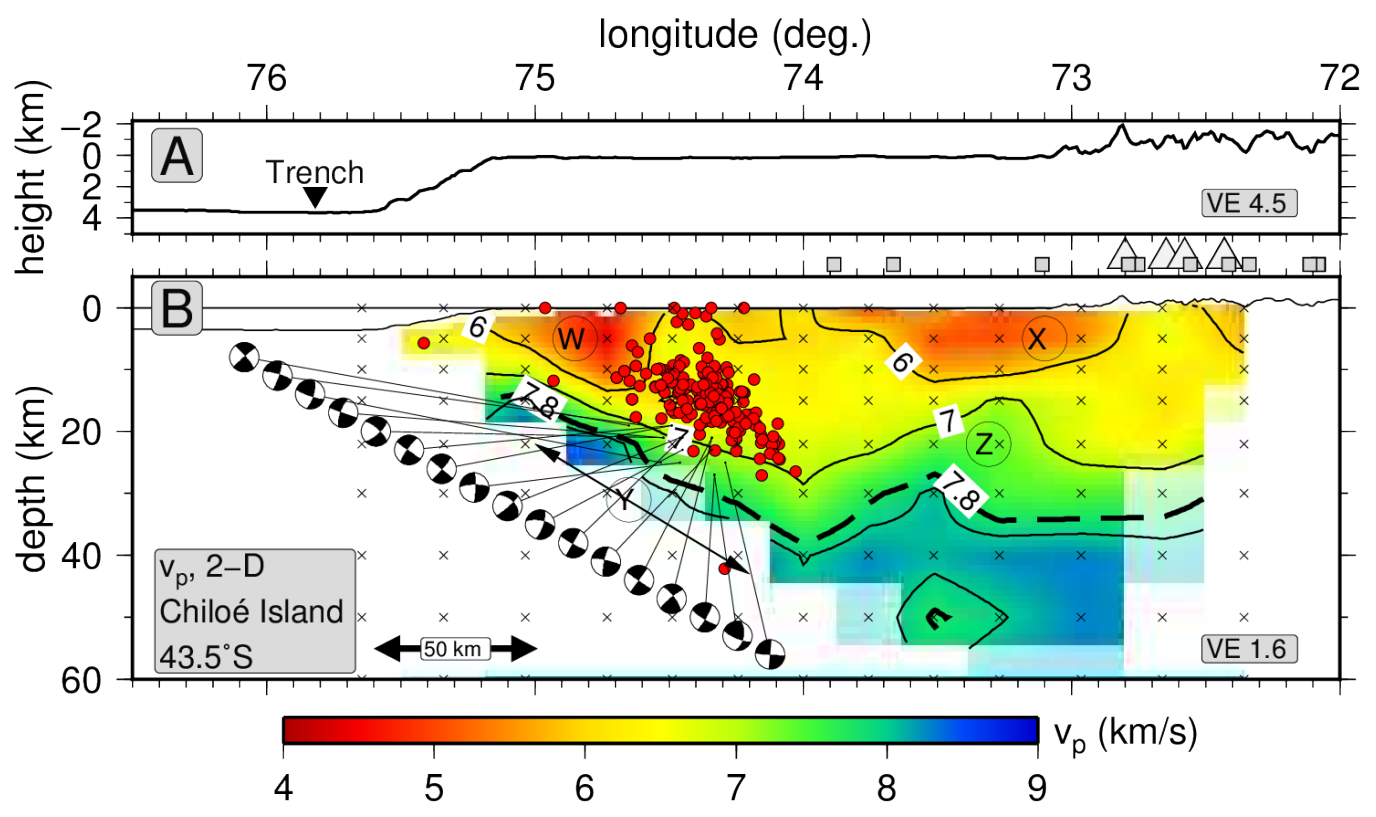

Figure 7: Profiles along the 2016 Chiloé rupture. A.) West-east striking topographic profile. B.) Section showing the aftershock seismicity superimposed on the 2-D vp velocity model from Lange (2008). Red circles indicate aftershocks of the 2016 Chiloé event. Events are shown within $120 \mathrm{~km}$ of either side for the profile centred at $43.5^{\circ} \mathrm{S}$. The land stations from CSN and active volcanoes are indicated with boxes and triangles, respectively. Model nodes are plotted as crosses. The velocity model is clipped in areas where the resolution of the model is low. See section 4.4 for explanation of characters " $W$ " to " $Z$ ". 

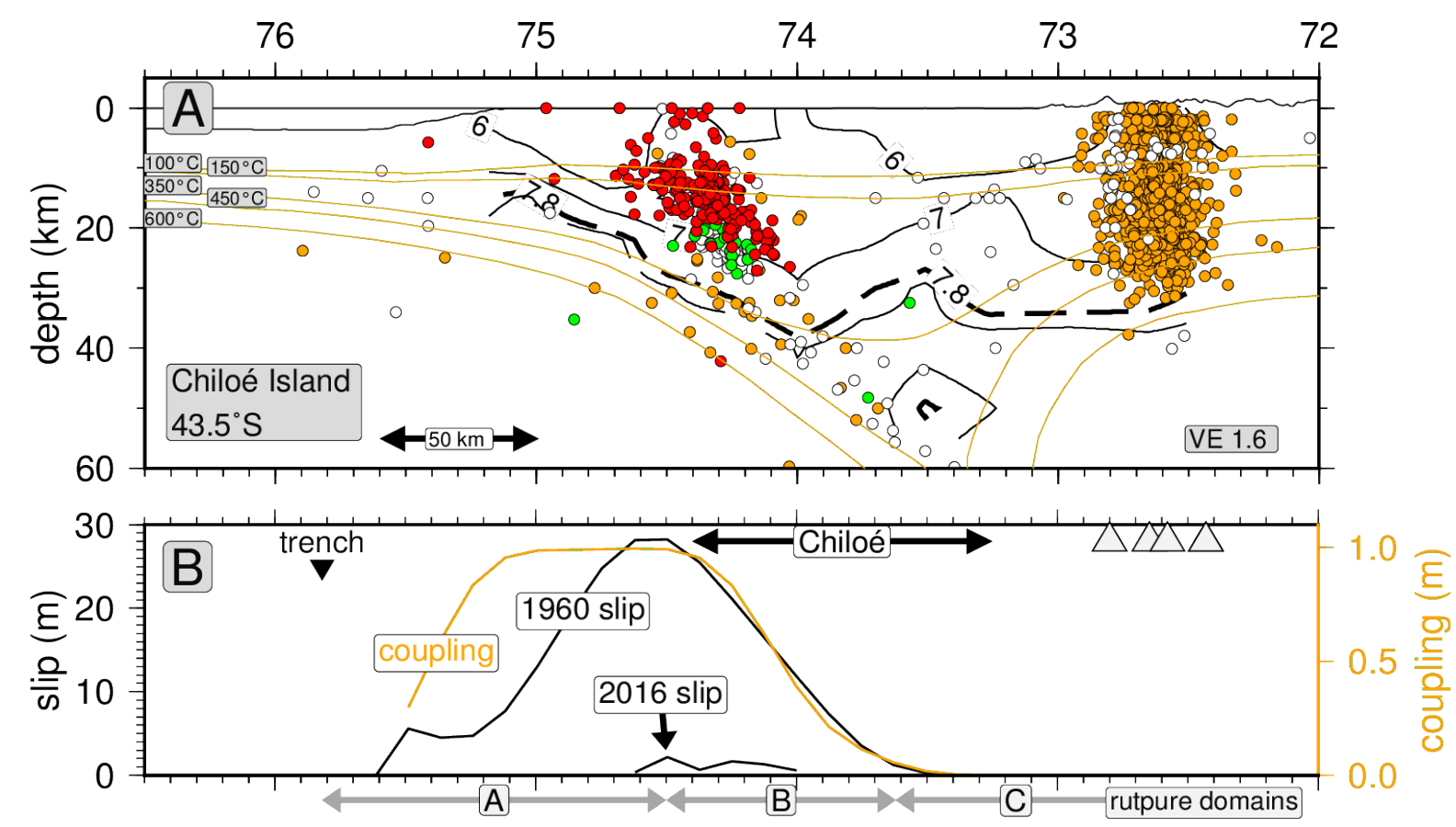

Figure 8: A.) East-west profile showing the distribution of interseismic activity (orange: CSN catalogue, 01/01/2008-2016 until 24/12/2016), white: interseismic activity from Lange et al. (2007), green: foreshock seismicity of the 2016 Chiloé earthquake, red: aftershock seismicity of the 2016 Chiloé earthquake. Interseismic activity of the magmatic arc (orange circles $\sim 72.8^{\circ} \mathrm{W}$ ) is related to the eruption of Chaitén volcano in 2008. Events are shown within $120 \mathrm{~km}$ of either side for the profile centred at $43.5^{\circ} \mathrm{S}$. The orange lines indicate isotherms from the thermal model of Völker et al., 2011. B.) Vertical west-east trending profile for $43.5^{\circ} \mathrm{S}$ showing the interseismic coupling (Moreno et al., 2011), slip of the 1960 Valdivia earthquake (Moreno et al., 2009) together with the co-seismic slip of the 2016 Chiloé earthquake. Rupture domains following the classification of Lay et al. 2012 are indicated with grey arrows. The land stations and active volcanoes are indicated with boxes and triangles, respectively. 